\title{
An evaluation of Wheat based Cropping System with Nutrient Management of kharif Crop Soybean
}

\author{
H. S. Kushwaha and Aditya Kumar Singh*
}

Mahatma Gandhi Chitrakoot Gramodaya Vishwavidyalaya, Chitrakoot, Satna, M. P., India

*Corresponding author

\section{A B S T R A C T}

Keywords

Wheat, Soybean, Nutrients, Soil test crop result, Vermi compost, Yield and Economics

Article Info

Accepted:

15 November 2019

Available Online:

10 December 2019
The study was conducted at research field of Krishi Vigyan Kendra, Ganiwan, Chitrakoot (U.P.) on Ph. D. work topic of "Diversification of wheat (Triticum aestivum L.) based cropping system with nutrient management in Central Plateau of Uttar Pradesh" during the year 2014-15 and 2015-16, to study the effect of soil test based crop response technology on yield and economics of wheat. The yield of wheat $2357.67 \mathrm{~kg} / \mathrm{ha}$ achieved with application of N: P: K as $200 \%$ and yield of $4283.84 \mathrm{~kg} / \mathrm{ha}$ is achieved with application of N: P: K as $175 \%$ along with 2 tone Vermi compost. On the basis of soil test value condition of wheat cultivation B: C ratio is 1.81. Hence combination of vermi - compost and inorganic fertilizer could achieve maximum yield and maintain the soil fertility status.

\section{Introduction}

Wheat (Triticum aestivum $L$ ) is one of the most important food grain crops in the world. In our country it is placed just after paddy in terms of production and consumption. It is consumed mostly in the form of "Chapatti". Wheat straw is used for feeding the cattle. Wheat grain contains more than 11 percent protein than other cereals and has a relatively high content of niacin and thiamine. It is basically concerned in providing the characteristics substance "gluten" which is very essential for bakers.
Wheat is most important winter crop grown in India during Rabi season from November to April. The overall production of wheat in India has gone tremendously from 12.8 million tons in 1966 to a record height 86.87 million tons. The productivity has increased from 887 to $2900 \mathrm{~kg} / \mathrm{ha}$. For the production point of view India is the second wheat growing country after China in the world.

Wheat is cultivated in almost every state except Kerala. Based on the agro-climatic conditions and varying agro ecological 
production conditions, the country is broadly divided into six wheat growing zones. The maximum wheat growing duration is in Northern Hill Zone and minimum in Peninsular Zone.

The latest development in Mexican wheat and advanced production technology has made it possible to harvest more than 5 tons/ha of wheat grains. But the availability of per capita wheat which has increased by 300 percent over the past 30 years show that by 2020 AD the present level of 185 gram per capita per day will rise to 220 gram and the 1.3 billion feeding mouth that time in the country will require 105 million tons of wheat.

Uttar Pradesh is the premier wheat production state, which shares were than 36 percent both in the area and production in the country. The state occupies an area of 8.99 million hectares and has record production of 24.33 million tons with productivity of $26.59 \mathrm{q} / \mathrm{ha}$.

\section{Materials and Methods}

The material and techniques adopted the course of investigation two consecutive years (kharif, Rabi 2014-2015 and 2015-2016) along with a description of edaphic and climatic conditions under which the trial was conducted.

\section{Experimental site}

The experiments were lay out at Tulsi Krishi Vigyan Kendra, Ganiwan, Chitrakoot, U.P. on clay loam soil along with a description of edaphic and climatic conditions under which the experiment was conducted.

\section{Climate}

Geographically, Chitrakoot falls in central plateau of Uttar Pradesh and is situated at $80^{0} 58^{\prime}$ to $81^{0} 34^{\prime}$ east longitude and $24^{0} 48^{\prime}$ to north latitude. It is situated at an elevation of $125.90 \mathrm{~m}$ above mean sea level. The mean annual rainfall of the district is $802 \mathrm{~mm}$.

\section{Details of experimental design and lay out}

A four replicated Randomized Block Design was adopted during both the years of experimentation for according the treatments.

\section{Experimental treatments}

Symbols: In this investigation the treatments with symbols are given in Table 1.

\section{Results and Discussion}

Grain yield (G) per plant and grain yield Kg per hectare

The data regarding on grain yield per plant $(\mathrm{g})$ and 1000, grain yield $\mathrm{kg}$ per hectare of soybean were tabulated and analyzed statistically and the results have been presented in Table 2, the mean value of various treatment also depicted by graphically in Figure 1.

It is obvious from the result Table 2 showed that the various treatments significantly influence the grain yield (g) per plant and with the application of T4 treatment bigger significantly over rest treatments of soybean in both the year.

It is noticeable from the result Table 2 showed that the various treatment significantly influence the grain yield $(\mathrm{kg} / \mathrm{ha})$ of soybean and with the application of $\mathrm{T} 4$ treatment increased significantly over rest treatment in both the year.

\section{Straw yield and biomass yield Kg/ha}

The data regarding on straw yield $(\mathrm{kg} / \mathrm{ha})$ and biomass yield $(\mathrm{kg} / \mathrm{ha})$ of soybean were 
tabulated and analyzed statistically and the results have been presented in Table 3 , the mean value of various treatment also depicted by graphically in Figure 2 .

It is obvious from the result Table 3 showed that the various treatments significantly influence the straw yield $(\mathrm{kg} / \mathrm{ha})$ and with the application of T4 treatment bigger significantly over rest treatments of soybean in both the year.

It is noticeable from the result Table 3 showed that the various treatment significantly influence the biomass yield $(\mathrm{kg} / \mathrm{ha})$ of soybean and with the application of $\mathrm{T} 4$ treatment increased significantly over rest treatment in both the year.

Table.1 Treatments symbols for kharif and rabi crops

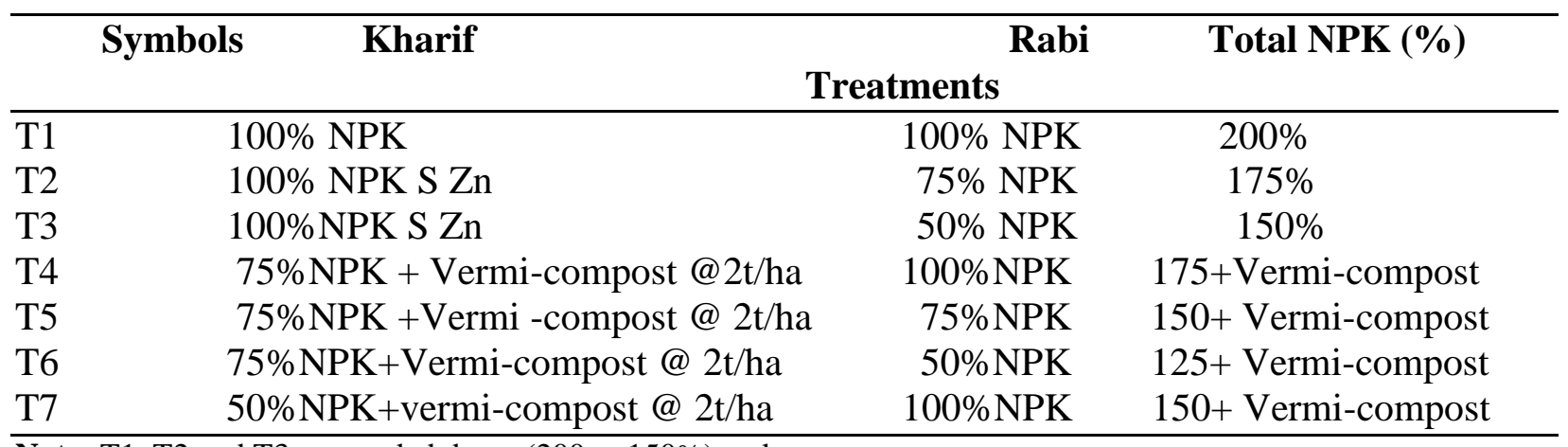

Note: T1, T2 and T3 are graded doses (200 to $150 \%)$ and

$\mathrm{T} 4, \mathrm{~T} 5$ and $\mathrm{T} 6$ are also graded doses involving vermi compost (175 to $125 \%$ )

$\mathrm{T} 1, \mathrm{~T} 4$ and T7 could be recommended if trial conducted nicely and control Treatments.

Table.2 Effect of various nutrients on grain yield $(\mathrm{g})$ per plant at maturity and grain yield $\mathrm{kg} / \mathrm{ha}$ of soybean in 2014-15 and 2015-16

\begin{tabular}{|c|c|c|c|c|}
\hline Treatments & $\begin{array}{c}\text { Grain yield (g)/ } \\
\text { Plant in 2014-15 }\end{array}$ & $\begin{array}{c}\text { Grain yield (g)/ } \\
\text { plant in 2015-16 }\end{array}$ & $\begin{array}{c}\text { Grain yield } \\
\text { kg/ha in 2014-15 }\end{array}$ & $\begin{array}{c}\text { Grain yield } \\
\text { kg/ha in 2015-16 }\end{array}$ \\
\hline T1 & 6.05 & 6.23 & 2014.48 & 2073.23 \\
\hline T2 & 7.91 & 8.11 & 2633.75 & 2701.31 \\
\hline T3 & 8.10 & 8.29 & 2696.34 & 2753.58 \\
\hline T4 & 9.88 & 10.23 & 3294.68 & 3399.57 \\
\hline T5 & 9.10 & 9.24 & 3024.93 & 3073.22 \\
\hline T6 & 9.16 & 9.13 & 3040.67 & 3042.83 \\
\hline T7 & 8.17 & 8.30 & 2718.42 & 2766.03 \\
\hline SE (d) & 0.19 & 0.44 & 86.23 & 138.19 \\
\hline CD (P=0.05) & 0.41 & 0.91 & 181.23 & 290.42 \\
\hline
\end{tabular}


Fig.1

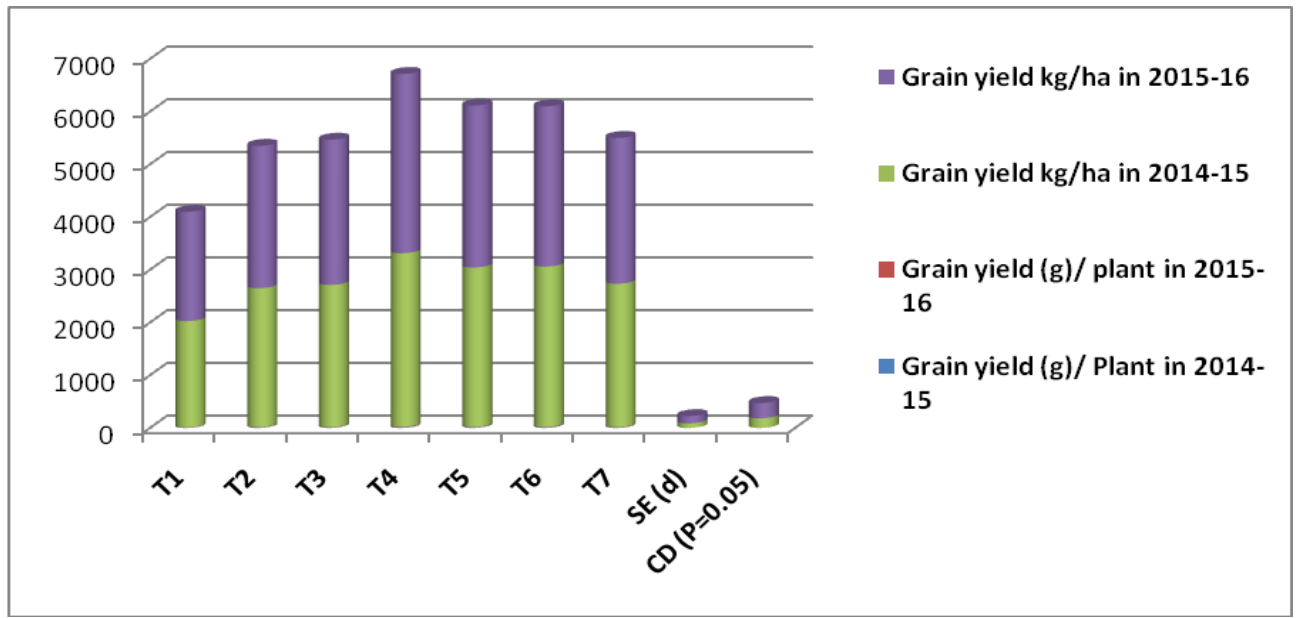

Fig.2

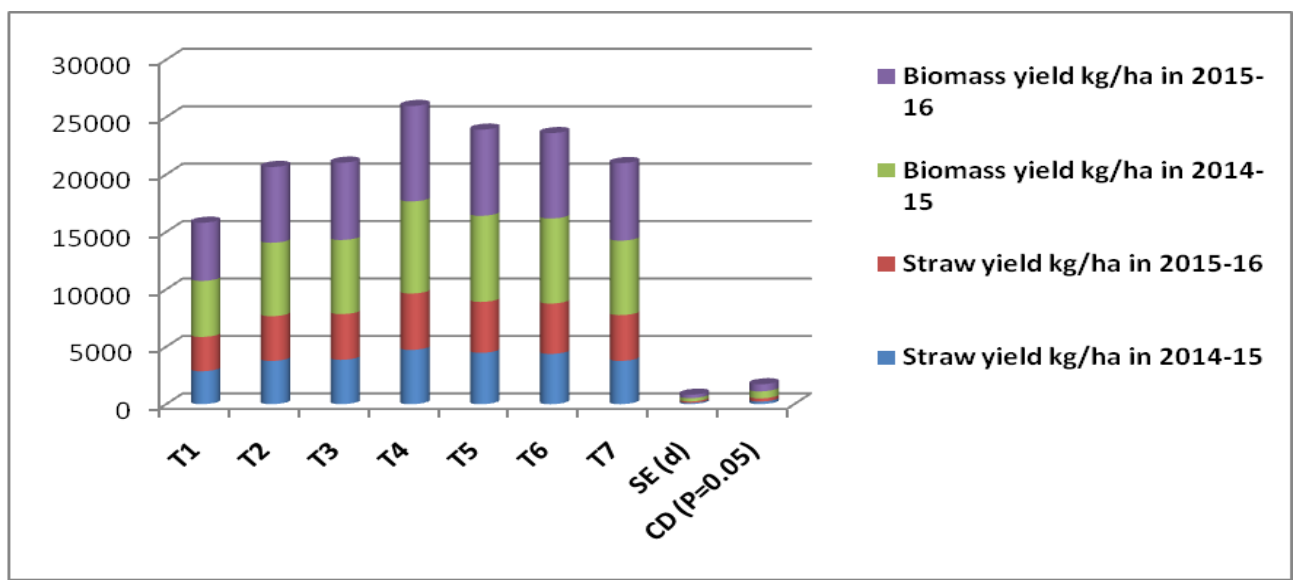

Fig 3

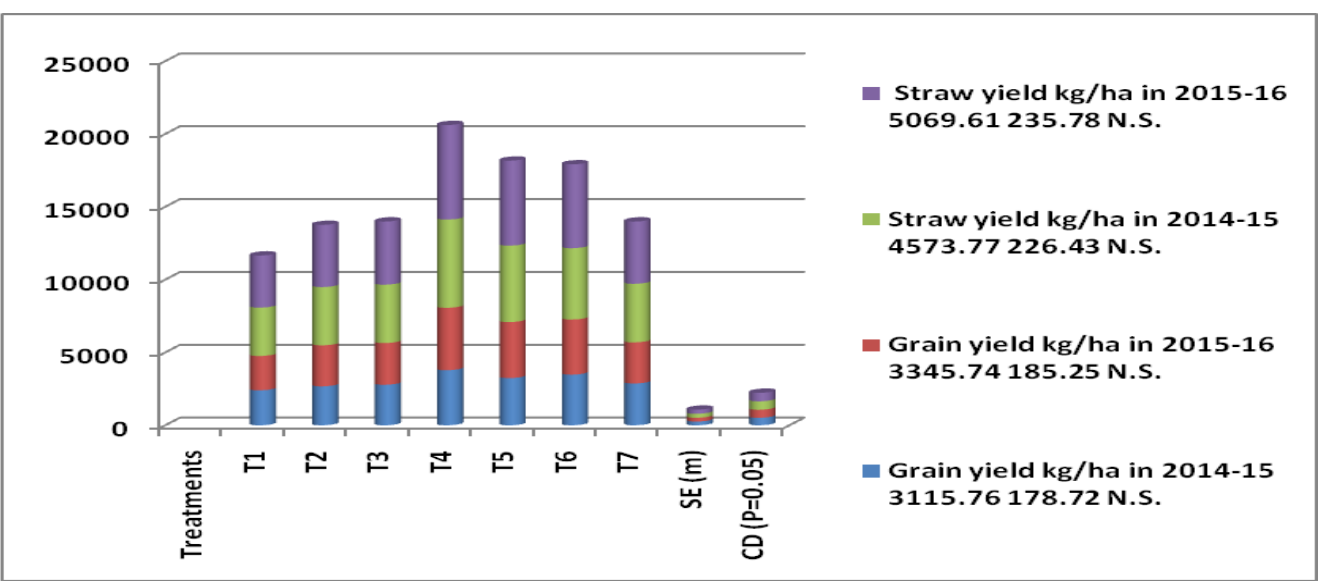


Table.3 Effect of various nutrients on straw yield and biomass yield $(\mathrm{kg} / \mathrm{ha})$ at maturity of soybean in 2014-15 and 2015-16

\begin{tabular}{|c|c|c|c|c|}
\hline Treatments & $\begin{array}{c}\text { Straw yield } \\
\text { kg/ha in 2014-15 }\end{array}$ & $\begin{array}{c}\text { Straw yield } \\
\mathbf{k g} / \mathbf{h a ~ i n ~ 2 0 1 5 - 1 6}\end{array}$ & $\begin{array}{c}\text { Biomass yield } \\
\mathbf{k g} / \mathbf{h a ~ i n ~ 2 0 1 4 - 1 5}\end{array}$ & $\begin{array}{c}\text { Biomass yield } \\
\mathbf{k g} / \mathbf{h a} \text { in 2015-16 }\end{array}$ \\
\hline T1 & 2866.74 & 2990.75 & 4881.22 & 5063.98 \\
\hline T2 & 3764.32 & 3897.40 & 6398.07 & 6598.71 \\
\hline T3 & 3864.63 & 3977.68 & 6460.65 & 6731.26 \\
\hline T4 & 4725.47 & 4912.08 & 8020.15 & 8311.65 \\
\hline T5 & 4470.05 & 4436.05 & 7494.98 & 7509.27 \\
\hline T6 & 4373.25 & 4390.10 & 7413.85 & 7432.93 \\
\hline T7 & 3768.08 & 3988.28 & 6486.50 & 6754.31 \\
\hline SE (d) & 108.66 & 132.37 & 288.95 & 295.45 \\
\hline CD (P=0.05) & 228.37 & 278.149 & 607.08 & 620.74 \\
\hline
\end{tabular}

Table.4 Effect of crop soybean and various nutrients on grain yield $\mathrm{kg} / \mathrm{ha}$ and straw yield $\mathrm{kg} / \mathrm{ha}$ at maturity of wheat in 2014-15 and 2015-16

\begin{tabular}{|c|c|c|c|c|}
\hline Crop & $\begin{array}{c}\text { Grain yield } \\
\text { kg/ha in 2014-15 }\end{array}$ & $\begin{array}{c}\text { Grain yield kg/ha } \\
\text { in 2015-16 }\end{array}$ & $\begin{array}{c}\text { Straw yield kg/ha } \\
\text { in 2014-15 }\end{array}$ & $\begin{array}{c}\text { Straw yield kg/ha } \\
\text { in 2015-16 }\end{array}$ \\
\hline Soybean & 3115.76 & 3345.74 & 4573.77 & 5069.61 \\
\hline SE (d) & 178.72 & 185.25 & 226.43 & 235.78 \\
\hline CD (P=0.05) & N.S. & N.S. & N.S. & N.S. \\
\hline Treatments & & & & \\
\hline T1 & 2403.44 & 2357.67 & 3322.39 & 3572.66 \\
\hline T2 & 2674.77 & 2816.55 & 4000.42 & 4268.11 \\
\hline T3 & 2782.85 & 2866.35 & 4006.67 & 4337.41 \\
\hline T4 & 3783.23 & 4283.84 & 6058.08 & 6490.08 \\
\hline T5 & 3242.85 & 3846.02 & 5252.40 & 5830.33 \\
\hline T6 & 3478.96 & 3787.19 & 4895.27 & 5754.72 \\
\hline T7 & 2872.30 & 2823.23 & 4020.51 & 4276.70 \\
\hline SE (m) & 258.68 & 262.45 & 274.45 & 278.95 \\
\hline CD (P=0.05) & 518.73 & 551.41 & 576.62 & 586.07 \\
\hline
\end{tabular}

\section{Grain and Straw Yield Kg/Ha Of Wheat Crop}

The regarding to number of grain yield $\mathrm{kg} / \mathrm{ha}$ and straw yield $\mathrm{kg} / \mathrm{ha}$ of wheat at maturity tabulated and analyzed statistically, the results have been presented in result Table 4, the mean values also depicted by graphically in figure 3 .

\section{Grain yield kg/ha}

\section{Effect of cropping system}

It is obvious from the result Table 4 showed that the different crops failed to touch the level of significant in connection of grain yield $\mathrm{kg} / \mathrm{ha}$ of wheat, but after soybean the grain 
yield $\mathrm{kg} / \mathrm{ha}$ statistically higher in both the years.

\section{Effect of nutrients}

It is evident from the result Table 4 showed that the various nutrient significantly ability the grain yield $\mathrm{kg} / \mathrm{ha}$ at maturity of wheat crop and with the application T4 (100\% NPK +vermi-compost (Total NPK 175\%) found significantly enhanced and T1 $200 \%$ NPK found significantly lowest in both the year.

\section{Straw yield kg/ha}

\section{Effect of cropping system}

It is prominent from the result Table 4 showed that the different crops failed to touch the level of significant in connection of straw yield $\mathrm{kg} / \mathrm{ha}$ of wheat, but after Soybean the straw yield $\mathrm{kg} / \mathrm{ha}$ statistically higher in both the years.

\section{Effect of nutrients}

It is able to be seen from the result Table 4 showed that the various nutrient significantly influence the straw yield $\mathrm{kg} / \mathrm{ha}$ at maturity of wheat crop and with the application T4 (100\% NPK + vermi - compost (Total NPK 175\%) found significantly superior and T1 $200 \%$ NPK found significantly lowest in both the year.

\section{References}

Aggarwal, N., Ram, H., Singh, G., and Kaur, J. 2014. Effect of sowing dates, sowing methods and seed rate on productivity, heat utilization and irrigation efficiency of soybean (Glycine max L.). In SOYCON 2014. Mitigating Productivity Constraints in Soybean for Sustainable Agriculture. Indore, 22-24 February 2014.
Allen Jr., L.H., Boote, K.J., Jones, J.W., Jones, P.H., Valle, R.R., Acock, B., Rogers, H.H. and Dahlman, R.C. 1987. Response of vegetation to rising carbon dioxide: Photosynthesis, biomass, and seed yield of soybean. Global Biogeochemical Cycles 1, 1-14. Aulakh, M.S., Pasricha, N.S. and Bahl, G.S. 2003. Phosphorus fertilizer response in an irrigated soybean-wheat production system on a subtropical, semiarid soil. Field Crops Research 80, 99-109.

Bandyopadhyay, K.K., Misra, A.K., Ghosh, P.K. and Hati, K.M. 2010. Effect of integrated use of farmyard manure and chemical fertilizers on soil physical properties and productivity of soybean. Soil and Tillage Research 110, 115125.

Behera, U.K., Sharma, A.R. and Pandey, H.N. 2007. Sustaining productivity of wheat-soybean cropping system through integrated nutrient management practices on the vertisols of central India. Plant and Soil 297, 185-199.

Bhatnagar, P.S. and Joshi, O.P. 1999. Soybean in cropping systems in India. FAO Series on Integrated Crop Management, pp.39. FAO, Rome, Italy.

Bhattacharyya, R., Prakash, V., Kundu, S., Ghosh B.N., Srivastva, A.K. and Gupta H.S. 2006. Potassium balance as influenced by farmyard manure application under continuous soybeanwheat cropping system in a Typic Haplaquept. Geoderma 137, 155-160.

Bhattacharyya, R., Kundu, S., Prakash, V. and Gupta, H.S. 2008. Sustainability under combined application of mineral and organic fertilizers in a rainfed soybean- wheat system of the Indian Himalayas. European Journal of Agronomy 28, 33-46.

Billore, S.D., Vyas, A.K., Ramesh, A., Joshi, 
O.P. and Khan, I.R. 2008. Sustainability of soybean (Glycine max) - wheat (Triticum aestivum) cropping system under integrated nutrient management. Indian Journal of Agricultural Sciences 78, 358-361.

Chaudhary, R.S., Hati, K.M., Saha, R. and Somasundaram, J. 2013. Crop diversification in Vertisol region for higher productivity. In IISS Contribution in Frontier Areas of Soil Research, pp. 201-220. ICAR - Indian Institute of Soil Science, Bhopal.

Curry, R.B., Jones, J.W., Boote, K.J., Peart, R.M.L., Allen, H. and Pickering, N.B. 1995. Response of soybean to predicted climate change in the USA. In Climate Change and Agriculture: Analysis of Potential International Impacts (C. Rosenzweig, Ed.). ASA Special Publication 59, 163-182.

Desclaux, D., and Roumet, P. 1996. Impact of drought stress on the phenology of two soybean (Glycine max L. Merr) cultivars. Field Crops Research 46, 61-70.

Dornbos Jr., D. L., and Mullen, R.E. 1992. Soybean seed protein and oil contents and fatty acid composition adjustments by drought and temperature. Journal of the American Oil Chemists Society 69, 228-231.

Ganeshamurthy A.N. and Reddy, K.S. 2000. Effect of integrated use of farmyard manure and sulphur in a soybean and wheat cropping system on nodulation, dry matter production and chlorophyll content of soybean on swell-shrink soils in central India. Journal of Agronomy and Crop Science 185, 9197.

Gibson, L.R., and Mullen, R.E. 1996. Soybean seed composition under high day and night growth temperatures. Journal of American Oil Chemists Society 73, 733-737.

Goel, O.P. 2014. The status of Indian soybean industry and its future. In SOYCON 2014. Mitigating Productivity Constraints in Soybean for Sustainable Agriculture, p. 90. Indore, 22-24 February 2014.

Jancic, M., Lalic, B., Mihailovic, D.T. and Jacimovic, G. 2015. Impact of climate change and carbon dioxide fertilization effect on irrigation water demand and yield of soybean in Serbia. The Journal of Agricultural Science doi: 10.1017/ S0021859615000179.

\section{How to cite this article:}

Kushwaha, H. S. and Aditya Kumar Singh. 2019. An evaluation of Wheat based Cropping System with Nutrient Management of kharif Crop Soybean. Int.J.Curr.Microbiol.App.Sci. 8(12): 2106-2112. doi: https://doi.org/10.20546/ijcmas.2019.812.249 